\title{
Assessment of Bone Mineral Density in Patients with Incidental Parathyroidectomy during Thyroidectomy
}

\author{
Tiroidektomi Yapılan Hastalarda Insidental Paratiroidektominin Kemik Mineral \\ Yoğunluğuna Etkisi
}

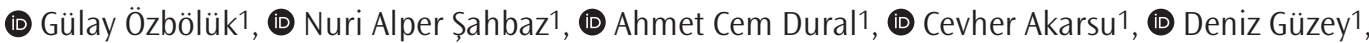 \\ (1) Fatmagül Kuşku Çabuk2², (1) Sema Çiftçi Doğanșen³, (1) Serdar Altınay², (1) Mehmet Karabulut¹
}

\begin{abstract}
1University of Health Sciences Turkey, Bakırköy Dr. Sadi Konuk Training and Research Hospital, Department of General Surgery, İstanbul, Turkey 2University of Health Sciences Turkey, Bakırköy Dr. Sadi Konuk Training and Research Hospital, Department of Pathology, İstanbul, Turkey 3University of Health Sciences Turkey, Bakırköy Dr. Sadi Konuk Training and Research Hospital, Department of Endocrinology and Metabolism,
\end{abstract} İstanbul, Turkey

\begin{abstract}
Introduction: Thyroid surgery for benign and malign diseases is one of the most common procedures performed in surgical practice. Complication rates are higher in malignant and inflammatory diseases, recurrent surgeries and in hyperthyroid patients. Hypocalcemia is one of these complications. There are many studies investigating the effect of incidental parathyroid tissue removal on hypocalcemia in thyroidectomy operations and investigating the risk factors for incidental parathyroidectomy. However, there are no studies investigating the effect on bone mineral density (BMD). In our study, we aimed to reveal the effect of incidental parathyroidectomy during total thyroidectomy (TT) on BMD and osteoporosis.
\end{abstract}

Methods: Between January 2013 and December 2016, pathology reports of 983 patients who underwent TT, completion thyroidectomy, TT + central neck dissection, TT + functional neck dissection, TT + modified radical neck dissection were retrospectively reviewed.

Seventy-two female patients with incidental parathyroid tissue were included in the study. Demographic information, postoperative biochemical values (calcium, albumin, parathyroid hormone, vitamin D, phosphorus, alkaline phosphatase), BMD, The World Health Organization Frakture Risk Assessment Tool (FRAX) fracture risks were recorded and the relationship between them was evaluated.

Results: Patients were divided into three groups according to BMD: normal, osteopenic and osteoporotic. Patients in menopause and patients older than 45-years were more in osteopenic and osteoporotic group. Patients undergoing extended surgery had more parathyroids removed. There was no correlation between the number of parathyroid glands

\section{ÖZ}

Amaç: Benign ve malign hastalıklar için uygulanan tiroid cerrahisi, cerrahi pratiğinde en sıkyapılan girişimler arasındadır. Malign hastalıklar, enflamatuvar hastalıklar, tekrarlayan cerrahiler ve hipertiroidili hastalarda komplikasyon oranları daha fazladır. Bu komplikasyonların bașında hipokalsemi gelmektedir. Litaratürde tiroidektomi ameliyatlarında insidental paratiroid dokusu çıkarılmasının hipokalsemi üzerine etkisini araștıran ve insidental paratiroidektomiye neden olan risk faktörlerini araştıran pek çok çalışma mevcuttur. Ancak kemik mineral yoğunluğuna (KMY) etkisini araștıran çalışmalar yoktur. Çalışmamızda, total tiroidektomi (TT) esnasında insidental paratiroidektominin KMY'ye ve osteoporoz üzerine etkisini ortaya çıkarmaktır.

Yöntemler: Ocak 2013 ile Aralık 2016 tarihleri arasında multinodüler guatr, graves, toksik multinodüler guatr, malignite tanılarıyla TT, tamamlayıcı tiroidektomi, TT + santral boyun diseksiyonu, TT + fonksiyonel boyun diseksiyonu, TT + modifiye radikal boyun diseksiyonu ameliyatı yapılan 983 hastanın patoloji raporları retrospektif olarak incelendi. Insidental paratiroid dokusu saptanan 72 kadın hasta çalışmaya dahil edildi. Hastaların demografik bilgileri, post-operatif biyokimyasal değerleri (kalsiyum, albümin, parathormon, D vitamini, fosfor, alkalen fosfataz), KMY, Dünya Sağlık Örgütü Kırılma Riski Değerlendirme Aracı (FRAX) fraktü riskleri kaydedilerek aralarındaki ilişki değerlendirildi.

Bulgular: Hastalar KMY'ye göre normal, osteopenik ve osteoporotik olmak üzere üç gruba ayrıldı. Menopoz ve 45 yașın üzerinde olan hastalar osteopenik ve osteoporotik grupta daha fazlaydı. Genişletilmiş cerrahi uygulanan hastalarda

Phone: +90 5055572762 E-mail: alpersahbaz@yahoo.com ORCID ID: orcid.org/0000-0002-0668-8382

Cite this article as/Atıf: Özbölük G, Şahbaz NA, Dural AC, Akarsu C, Güzey D, Kușku Çabuk F, Çiftçi Doğanșen S, Altınay S, Karabulut M. Assessment of Bone Mineral Density in Patients with Incidental Parathyroidectomy during Thyroidectomy. İstanbul Med J 2020; 21(4): 320-6.

(C) Copyright 2020 by the University of Health Sciences Turkey, Istanbul Training and Research Hospital/Istanbul Medical Journal published by Galenos Publishing House

(C) Telif Hakkı 2020 Sağılk Bilimleri Üniversitesi Istanbul Eğitim ve Araştırma Hastanesi/Istanbul Tıp Dergisi, Galenos Yayınevi tarafından basılmıștır. 
removed and hypocalcemia. After the surgery, the patients had no harmful effects on BMD and FRAX fracture risk.

Conclusion: In our study, one or two parathyroid glands were removed. No effect on BMD was detected.

Keywords: Incidental parathyroidectomy, bone mineral density, thyroidectomy daha fazla sayıda paratiroid çıkarılmıștı. Çıkarılan paratiroid sayısıyla hipokalsemi arasında bağlantı saptanmadı.

Sonuç: Çalışmamızda, bir veya iki paratiroid bezinin çıkartılmasının KMY üzerine herhangi bir etkisi saptanmadı.

Anahtar Kelimeler: İnsidental paratiroidektomi, kemik mineral yoğunluğu, tiroidektomi

\section{Introduction}

Total thyroidectomy (TT) is the most commonly preferred method for the treatment of malignant and benign thyroid diseases. The most common complication in the post-operative period is approxiately onethird of hypocalcemia. Hypocalcemia may develop due to intraoperative manipulation of parathyroid glands, injury, accidental removal or deterioration of blood supply and is the most important factor leading to prolonged hospitalization (1-3).

Hypocalcemia that develops after TT is usually temporary. The incidence of persistent hypocalcemia depends on the experience of the clinic, but is reported between $0-13 \%$ in the literature (4).

When central neck dissection is added to TT, this rate increases to $1 \%$ $15 \%(5,6)$

The risk of complications of TT is higher than that of limited surgery (such as lobectomy) resections. There is a higher rate of complication in diseases such as malignant diseases, inflammatory diseases, recurrent surgeries and hyperthyroidism. The experience of the surgeon performing the surgery and anatomical variations are also effective on complications (7).

Parathyroid hormone (PTH); plays an important role in the regulation of bone metabolism. PTH provides calcium balance by increasing calcium absorption through vitamin D from the intestine, reducing direct excretion from the kidney and directly increasing bone resorption (8).

Hypoparathyroidism is a factor that increases bone mineral density (BMD) (9). Although hypoparathyroidism may be idiopathic, it is often seen after thyroid surgery.

Osteoporosis is generally evaluated by the determination of BMD measured using the "Dual-Energy X-ray Absorptiometry (DEXA)" method. While it does not show other factors that may affect bone fragility, such as bone architecture and geometry, BMD is a very useful method for estimating bone strength and fracture risk $(10,11)$.

There are many studies in the literature that investigate the effect of removal of incidental parathyroid tissue on hypocalcemia in thyroidectomy surgeries and investigate the risk factors that cause incidental parathyroidectomy. However, there are no studies investigating its effect on BMD. Our aim in this study is to reveal the effect of incidental parathyroidectomy on BMD and osteoporosis during TT.

\section{Methods}

In University of Health Sciences Turkey, Bakırköy Dr. Sadi Konuk Training and Research Hospital, Department of General Surgery, patients diagnosed with multinodular goiter, Graves, toxic multinodular goiter and malignancy; pathology reports of 983 patients who underwent TT, complementary thyroidectomy, TT + central neck dissection, TT + functional neck dissection, TT + modified radical neck dissection surgery were analyzed retrospectively between January 2013 and December 2016.

Seventy two female patients with incidental parathyroid tissue were included in the study. The operations were performed by four experienced endocrine surgeons in the General Surgery Clinic. Postoperative pieces were evaluated by experienced pathologists in the Pathology unit. Ethics commitee approval was received for the study University of Health Sciences Turkey, Bakırköy Dr. Sadi Konuk Training and Research Hospital (decision no: 20.03.2018, protocol no: 81). Informed consent was obtained from the patients who participated in the study.

The data of the patients were analyzed retrospectively. Patients' age, gender, body mass index (BMI), date of surgery, indication for surgery, post-operative pathology results, number of parathyroids in the pathology specimen; post-operative urea, creatinine, total protein, albumin, calcium (Ca), vitamin D, PTH, phosphorus, alkaline phosphatase (ALP), thyroid stimulating hormone (TSH), T4, BMD were evaluated using DEXA. Patients were phoned and questioned about their height, weight, medical history, family history, alcohol use, smoking, menopause status, birth, steroid use and vitamin D use. Patients were classified according to the World Health Organization (WHO) definition of osteoporosis (normal with T-score -1 or above, osteopenic with T-score -1 to -2.5 , osteoporosis with T-score -2.5 or lower) (12).

A system called Fracture Risk Assessment Tool (FRAX) has been developed by the WHO's Center for Metabolic Bone Diseases cooperation to assess the 10-year fracture risk of diseases. In this system, age, gender, body weight, fracture history of patients and their parents, smoking, prolonged glucocorticoid use, rheumatoid arthritis, alcohol use, other causes of secondary osteoporosis were evaluated as the factors that determine absolute fracture risk for individuals. Finally, the WHO FRAX fracture index was calculated using https://www.sheffield.ac.uk web address.

The number of patients who underwent total tyroidectomy with clinical diagnosis of multinodular goiter, Graves' disease, toxic multinodular goiter, and malignancy and paratyhroid tissue detected in pathology reports were 107. However, 17 patients could not be reached by phone. The information in the file of thirteen patients was missing. Three patients did not want to participate in this study. Since the patient had parathyroid adenoma with thyroidectomy, 2 patients were excluded from the study and 72 women were included in the study. 


\section{Statistical Analysis}

Descriptive statistics were used to define continuous variables (mean, standard deviation, minimum, median, maximum). Chi-square and Fisher exact test were used to examine the relationship between categorical variables.

Multiple linear regression analysis was applied to examine the effect of independent variables on continuous dependent variables. In order to examine the effect of independent variables on two categories of dependent variables, binary logistic regression analysis was applied. In order to study the effect of independent variables on dependent variables with more than two categories, multinomial logistic regression analysis was applied.

The statistical significance level is 0.05 . The analyses were performed using Madcalc Statistical Software version 12.7.7 (MadCalc Statistical bvba, Ostend, Belgium).

\section{Results}

Seventy-two female patients were included in the study. Patients were evaluated according to WHO definition of osteoporosis. It was divided into three groups as osteoporotic, osteopenic and normal BMD. The data of the three groups were evaluated comparatively. The presence of fracture anamnesis did not make a statistically significant difference between the groups $(p=0.895)$. Thirty five $(46.6 \%)$ of the patients were premenopausal and 37 (52.4\%) were postmenopausal. Sixteen (40\%) of patients with normal BMD, 8 (38.1\%) of patients with osteopenic BMD and $11(100 \%)$ of patients with osteoporotic BMD were postmenopausal $(\mathrm{p}<0.001)$.

There was also no statistically significant difference between the groups whether the final pathology was benign or malignant $(p=0.055)$.

The mean age of patients with normal BMD was 43.5 (20-69), the mean age of patients with osteopenic BMD was 42 (32-77), and the mean age of patients with osteoporosis was 55 (43-80) $(p=0.004)$. Menopause was significantly higher in the osteoporosis group than in both normal and osteopenic groups $(p<0.001)$. BMI, parathyroid count in the specimen; and albumin, Ca, vitamin D, PTH, phosphorus and ALP were also found to have no differences between the groups (Table 1).

The relationship of FRAX fracture risk to the time elapsed after surgery was observed, and the increase in the time elapsed did not increase the risk (Table 2). DEXA was taken in 25 (34.7\%) patients 1-year after surgery, 21 (29.2\%) 2-years after surgery, 26 (36.1\%) more than 2-years after surgery. Likewise, osteopenia and osteoporosis were not related to the time elapsed after surgery (Table 2).

Patients according to the type of surgery performed were divided into two groups: Those who underwent TT and extended surgery (complementary thyroidectomy, TT + central neck dissection, TT + functional neck dissection, TT + modified radical neck dissection). FRAX fracture risk between these two groups; post-operative albumin, Ca, vitamin D, PTH, Phosphorus and ALP values and parathyroid count

Table 1. Comparison of parameters by groups

\begin{tabular}{|c|c|c|c|c|c|c|c|c|}
\hline & & Norr & & Oste & & Oste & & \\
\hline & & $\mathbf{n}$ & $\%$ & $\mathbf{n}$ & $\%$ & $\mathbf{n}$ & $\%$ & $\mathbf{p}^{n}$ \\
\hline Fracture anamnecis & Yes & 5 & 12.5 & 3 & 14.3 & 2 & 18.2 & 0.895 \\
\hline riaclute dilamitess & No & 35 & 87.5 & 18 & 85.7 & 9 & 81.8 & - \\
\hline & Yes & 16 & 40.0 & 8 & 38.1 & 11 & 100.00 & $<0.001$ \\
\hline IVIetiopause & No & 24 & 60.0 & 13 & 61.9 & 0 & 0.0 & - \\
\hline Pathrolorical diannoci & Benign & 26 & 65.0 & 7 & 35.0 & 8 & 72.7 & 0.055 \\
\hline 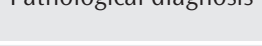 & Malignant & 14 & 35.0 & 13 & 65.0 & 3 & 27.3 & \\
\hline & & & & Ave & & Ave & & $\mathbf{p}^{* *}$ \\
\hline Age & & 43.88 & & 45.4 & & 58.6 & & 0.004 \\
\hline BMI & & 28.0 & & 29.2 & & 30.6 & & 0.519 \\
\hline Number of parathyroid & pecimen & 1.15 & & 1.14 & & $1 \pm 0$ & & 0.399 \\
\hline Post-op albumin (g/dL) & & 4.56 & & 4.47 & & 4.37 & & 0.530 \\
\hline Post-op Ca (mg/dL) & & 8.56 & & 8.74 & & 8.52 & & 0.536 \\
\hline Post-op Vitamin D (ng/ & & 18.2 & & 18.8 & & 24.5 & & 0.849 \\
\hline Post-op PTH (pg/mL) & & 37.0 & & $40 \pm$ & & 48.3 & & 0.088 \\
\hline Post-op phosphorus (m & & 3.97 & & 3.44 & & 3.73 & & 0.060 \\
\hline Post-op ALP (IU/L) & & 66.1 & & 63.3 & & 67.7 & & 0.999 \\
\hline Post-hoc paired comp & & $\begin{array}{l}\text { Norr } \\
\text { (p) }\end{array}$ & penic & $\begin{array}{l}\text { Nor } \\
\text { (p) }\end{array}$ & eoporotic & $\begin{array}{l}\text { Oste } \\
\text { (p) }\end{array}$ & Osteopo & \\
\hline Age & & 0.85 & & 0.00 & & 0.00 & & \\
\hline Menopause & & 1.00 & & 0.00 & & 0.00 & & \\
\hline
\end{tabular}


in pathology specimen were compared. Apart from the parathyroid number in specimen, no statistical significance was found in the others. The number of parathyroid patients in specimen was higher than in TT $(p=0.006)$. There was no significant difference between 2 groups in terms of osteopenia and osteoprosis development (Table 3).

\section{Discussion}

latrogenic hypoparathyroidism is a common complication after thyroidectomy (13). To reduce this complication, it is necessary to identify the parathyroid glands during surgery and to perform dissection close to the thyroid gland capsule so that it does not disrupt its blood supply $(14,15)$.

Hashimoto's thyroiditis $(16,17)$ and malignancies (18-23) pose a potential risk factor for insidental parathyroidectomy. Similarly, we found an increase in incidence parathyroidectomy after surgery due to malignancy.

In the literature, incidence parathyroidectomy rate is between 8-24.9\% $(24,25)$. In many studies in the literature, one pararthyroid gland was removed $(20,26,27)$. Similarly, most patients had a single parathyroid gland removed. Sixty-three (87.5\%) patients had one parathyroid gland removed, and 9 (12.5\%) patients had two parathyroid glands removed. The number of parathyroid glands three and above were not found in the specimens.
BMD is closely related to bone strength; prospective studies have shown that the risk of fracture increases with decreasing BMD and is an excellent indicator of possible future fracture risk. The risk of fracture increases twice with each standard deviation reduction in BMD (28).

Although patients with permanent hypoparathyroidism have an increase (9) in BMD, there are reports that contradict this information. Touliatos et al. (29) detected that eight patients with post-operative hypoparathyroidism have BMDs in the normal range.

In their study on 33 postmenopausal women who underwent TT, Fujiyama et al. (30) found that BMD of patients who developed hypoparathyroidism after surgery was higher than those with normal PTH levels. After this study, they concluded that hypoparathyroidism is protective against high bone mineral loss in the postmenopausal period. None of the patients we included in the study developed permanent hypoparathyroidism.

Mendonça et al. (31) did not find a significant difference between the BMDs of patients with hypoparathyroidism and patients with normal PTH levels in a controlled study conducted on 33 postmenopausal women.

Post-operative hypocalcemia is the most common complication that develops after TT and can develop due to many reasons (13).

In their study, Özden et al. (32) evaluated the temporal and permanent hypocalcemia rates in 178 patients who underwent thyroidectomy and

Table 2. Comparison of FRAX Fracture risk, osteopenic and osteoporotic BMD with the duration after the surgery

\begin{tabular}{|c|c|c|c|c|}
\hline & $<1$ Year & 1-2 Years & $>2$ Years & \multirow{2}{*}{$\mathrm{p}^{*}$} \\
\hline & Ave \pm SD & Ave \pm SD & Ave \pm SD & \\
\hline FRAX Fracture risk & $0.42 \pm 0.77$ & $0.46 \pm 1.15$ & $0.25 \pm 0.31$ & 0.973 \\
\hline Normal & $13(52 \%)$ & $12(57.1 \%)$ & $15(57.7 \%)$ & \multirow[b]{2}{*}{0.316} \\
\hline Osteoporotic & $10(40 \%)$ & $5(23.8 \%)$ & $6(23.1 \%)$ & \\
\hline
\end{tabular}

\section{Table 3. Comparison of parameters according to the type of surgery}

\begin{tabular}{|l|l|l|l|}
\hline & TT & Extended Surgery & p* \\
\hline & Ave \pm SD & Ave \pm SD & 0.514 \\
\hline FRAX Fracture & $0.35 \pm 0.6$ & $0.44 \pm 1.2$ & 0.427 \\
\hline Post-op Ca (mg/dL) & $8.7 \pm 0.6$ & $8.4 \pm 0.9$ & 0.305 \\
\hline Post-op vitamin D (ng/mL) & $18.9 \pm 13.8$ & $20.3 \pm 11.4$ & 0.161 \\
\hline Post-op PTH (pg/mL) & $41.1 \pm 18.9$ & $35.9 \pm 20$ & 0.995 \\
\hline Post-op phosphorus (mg/dL) & $3.8 \pm 0.8$ & $3.7 \pm 0.7$ & 0.614 \\
\hline Post-op ALP(IU/L) & $65.3 \pm 20.09$ & $66.1 \pm 15.9$ & 0.006 \\
\hline Number of parathyroid in specimen & $1.1 \pm 02$ & $1.3 \pm 0.5$ & $\mathbf{p}$ \\
\hline & $\mathbf{n}(\%)$ & $\mathbf{n}(\%)$ & $10(25 \%)$ \\
\hline Normal & $30(75 \%)$ & $8(57.1)$ & 0.412 \\
\hline Osteopenic & $13(59.1)$ & $2(42.9)$ & \\
\hline \begin{tabular}{l} 
Osteoporotic \\
\hline *Mann-Whitney U test, **chi-square, Ca: calcium, SD: standart deviation, Ave: average, post-op: post-operative, PTH: parathormone, TT: total thyroidectomy, FRAX: Fracture Risk \\
Assessment Tool, ALP: alkaline phosphatase
\end{tabular} & & \\
\hline
\end{tabular}


detected incidental parathyroid tissue in the pathology artery, and it was found that incidental parathyroidectomy had no effect on permanent hypocalcemia.

Manatakis et al. (33) evaluated 281 patients who underwent TT in their study. The patients were divided into two groups as those with and without incidental parathyroidectomy. Post-operative calcium levels were examined between these two groups. Hypocalcemia was observed in those who underwent incidental parathyroidectomy. However, there was no difference between the two groups in terms of symptomatic hypocalcemia.

Youssef et al. (20) included 207 patients who underwent total or unilateral thyroidectomy in their study. The patients were divided into two groups: 26 patients diagnosed with incidental parathyroidectomy and 181 patients not diagnosed incidental parathyroidectomy. Increased incidental parathyroidectomy rates were seen in surgeries where reoperation and neck dissection were also added. Post-operative hypocalcemia did not create a statistical difference between the two groups. This result was also reached in our study, and it was observed that more parathyroid tissue was removed in patients who underwent extended surgery compared to TT, and no permanent hypocalcemia occured in the patients.

Song et al. (34) examined the pathology specimens of 454 patients with TT. Incidental parathyroid tissue was detected in $19.8 \%$ of the patients in their pathology specimens. $17.6 \%, 1.5 \%$ and $0.7 \%$ of patients with incidental parathyroidectomy has one, two and three parathyroid tissues, respectively. It was observed that temporary hypoparathyroidism increased in proportion to the number of parathyroids removed. However, as a result, temporary or permanent hypocalcemia did not differ between these groups. In our study, hypoparathyroidism did not occur in the patients. One or two parathyroid glands were removed in our patients. Our results would have changed if three or more parathyroid glands were removed. This result, in fact, suggests that the amount of in vivo parathyroid tissue is more important.

Du et al. (35) found that surgeries in which central neck dissection was added poses a potential risk factor for incidental parathyrodectomy, in their study on 381 patients with TT and central neck dissection. Similar results were seen also in our study. The number of parathyroid glands removed in extended surgery was statistically significant $(p=0.006)$. However, there was no effect on osteoporosis, osteopenia and FRAX fracture risk.

Zheng et al. (36) divided 548 patients who underwent total and subtotal thyroidectomy into two groups, with and without incidental parathyroid tissue. In the group where incidental parathyroidectomy was performed compared to the non-performed group; transient hypocalcemia and recurrent laryngeal nerve injury rate were increased. Also, malignancy rate was higher in the group with incidental parathyroidectomy. Therefore, central lymph node dissection was applied to more patients than the other group.

Osteoporosis is a multi-cause and most common skeletal disease characterized by increased bone fragility due to decreased bone mass and disruption of the microstructure of bone tissue (37). Age is a very important factor in bone loss. Bone loss starts around the age of 40 , increases significantly in the 60 s, and is even higher in the 80 s (38). Low estrogen causes a decrease in bone mass. Therefore, menopause is also a risk factor for osteoporosis $(39,40)$. One of the other risk factors is the low BMI (37). In our study, we found that menopause and advanced age are risk factors for osteoporosis in accordance with the literature. However, BMI did not make a statistical difference between our patients.

Takamura et al. (41) included 140 patients who underwent TT. These patients were divided into three groups: transient hypoparathyroidic, persistent hypoparathyroidic and normal range. 5-years after the operation, DEXA were taken to the patients and evaluated the relation of hypoparathyroidism with BMD. It is concluded that temporary hypoparathyroidism increases BMD in postmenopausal women.

In the literature, any studies investigating the effect of the number of parathyroids removed on BMD were not found, and in our study we found that the number of parathyroids does not change BMD. However, one or two parathyroid tissues were removed in our patients who did not develop hypoparathyroidism later on.

\section{Conclusion}

As a result, when the groups were evaluated, it was seen that the number of parathyroids removed was significantly higher in patients who underwent extended surgery due to malignancy. Patients with a pathological diagnosis of malignancy were 5.68 times more at risk of osteopenia than benign ones. We think that this result is due to the suppression of TSH in malignant patients.

In our study, no effect on the risk of FRAX fractures observed caused by the duration after surgery. However, FRAX scores are calculated while FRAX fracture index is evaluated as 40-years-old in patients under 40-years-old and it is a subjective evaluation, therefore it may limit the results. In our study, one or two parathyroid tissues were removed incidentally. If three or more parathyroids are removed, results may vary and prospective studies should be conducted in relation to that.

\section{Ethics}

Ethics Committee Approval: Ethics commitee approval was received for the study University of Health Sciences Turkey, Bakırköy Dr. Sadi Konuk Training and Research Hospital (decision no: 20.03.2018, protocol no: 81).

Informed Consent: Informed consent was obtained from the patients.

Peer-review: Externally peer-reviewed.

Authorship Contributions: Surgical and Medical Practices - N.A.S., A.C.D., S.Ç.D., S.A., M.K.; Concept - G.Ö., N.A.Ş., A.C.D., C.A., F.K.Ç., S.Ç.D.; Design - G.Ö., N.A.S., A.C.D., C.A., S.A., M.K.; Data Collection or Processing - C.A., D.G., F.K.Ç., S.Ç.D.; Analysis or Interpretation - N.A.Ş., D.G., F.K.Ç., S.Ç.D., S.A., M.K.; Literature Search - G.Ö., C.A., D.G., F.K.C.., S.Ç.D., S.A.; Writing - G.Ö., N.A.S,., A.C.D., D.G., F.K.Ç., M.K.

Conflict of Interest: No conflict of interest was declared by the authors.

Financial Disclosure: The authors declared that this study received no financial support. 


\section{References}

1. Bergamaschi R, Becouarn G, Ronceray J, Arnaud JP. Morbidity of thyroid surgery. Am J Surg 1998; 176: 71-5.

2. Parmeggiani D, De Falco M, Avenia N, Sanguinetti A, Fiore A, Docimo G, et al. Nerve sparing sutureless total thyroidectomy. Preliminary study. Ann Ital Chir 2012; 83: 91-6.

3. Bhattacharyya N, Fried MP. Assessment of the morbidity and complications of total thyroidectomy. Arch Otolaryngol Head Neck Surg 2002; 128: 389-92.

4. Uludağ M, Besler E, Aygün N, Çitgez B, Mihmanlı M, Yetkin SG, et al. Tiroid cerrahisi sonrası hipokalsemi gelișimini etkileyen faktörler. Șișli Etfal Hastanesi Tıp Bülteni 2015; 49: 101-6.

5. Clarke BL, Brown EM, Collins MT, Jüppner H, Lakatos P, Levine MA, et al. Epidemiology and diagnosis of hypoparathyroidism. J Clin Endocrinol Metab. 2016 Mar 4. doi: 10.1210/jc.2015-3908. [Epub ahead of print].

6. Shoback DM, Bilezikian JP, Costa AG, Dempster D, Dralle H, Khan AA, et al. Presentation of hypoparathyroidism: etiologies and clinical features. J Clin Endocrinol Metab. 2016 Mar 4. doi: 10.1210/jc.2015-3909. [Epub ahead of print].

7. Lal G, Clark OH. Thyroid, parathyroid, and adrenal. Brunicardi FC, Andersen DK, Billiar TR, Dunn DL, Hunter JG, Matthews JB. editors. Schwartz's Principles of Surgery. 10th ed. New York: McGraw-Hill; 2014. p.1556.

8. Lal G, Clark OH. Thyroid, parathyroid, and adrenal. Brunicardi FC, Andersen DK, Billiar TR, Dunn DL, Hunter JG, Matthews JB. editors. Schwartz's Principles of Surgery. 10th ed. New York: McGraw-Hill; 2014. p.1558.

9. Abugassa S, Nordenström J, Eriksson S, Sjödén G. Bone mineral density in patients with chronic hypoparathyroidism. J Clin Endocrinol Metab 1993; 76: 1617-21.

10. Miller PD, Bonnick SL, Rosen CJ, Altman RD, Avioli LV, Dequeker J, et al. Clinical utility of bone mass measurements in adults: consensus of an international panel. The Society for Clinical Densitometry. Semin Arthritis Rheum 1996; 25: $361-72$.

11. Miller PD, McClung M. Prediction of fracture risk. I: Bone density. Am J Med Sci 1996; 312: 257-9.

12. Lal G, Clark OH. Thyroid, parathyroid, and adrenal. Brunicardi FC, Andersen DK, Billiar TR, Dunn DL, Hunter JG, Matthews JB. editors. Schwartz's Principles of Surgery 9th ed. New York: McGraw-Hill. 2010; p.2587-645.

13. Demeester-Mirkine N, Hooghe L, Van Geertruyden J, De Maertelaer V. Hypocalcemia after thyroidectomy. Arch Surg 1992; 127: 854-8.

14. Lappas D, Noussios G, Anagnostis P, Adamidou F, Chatzigeorgiou A, Skandalakis P. Location, number and morphology of parathyroid glands: results from a large anatomical series. Anat Sci Int 2012; 87: 160-4.

15. Praženica P, O'Driscoll K, Holy R. Incidental parathyroidectomy during thyroid surgery using capsular dissection technique. Otolaryngol Head and Neck Surg 2014; 150: 754-61.

16. Erbil Y, Barbaros U, Ozbey N, Aral F, Ozarmağan S. Risk factors of incidental parathyroidectomy after thyroidectomy for benign thyroid disorders. Int J Surg 2009; 7: 58-61.

17. Khairy GA, Al-Saif A. Incidental parathyroidectomy during thyroid resection: incidence, risk factors, and outcome. Ann Saudi Med 2011; 31: 274-8.

18. Ozoğul B, Nuran Akçay M, Kisaoğlu A, Atamanalp SS, Oztürk G, Aydinli B. Incidental parathyroidectomy during thyroid surgery: risk factors, incidence, and outcomes. Turk J Med Sci 2014; 44: 84-8.

19. Qasaimeh GR, Al Nemri S, Al Omari AK. Incidental extirpation of the parathyroid glands at thyroid surgery: risk factors and post-operative hypocalcemia. Eur Arch Otorhinolaryngol 2011; 268: 1047-51.
20. Youssef T, Gaballah G, Abd-Elaal E, El-Dosoky E. Assessment of risk factors of incidental parathyroidectomy during thyroid surgery: a prospective study. Int J Surg 2010; 8: 207-11.

21. Sippel RS, Ozgül O, Hartig GK, Mack EA, Chen H. Risks and consequences of incidental parathyroidectomy during thyroid resection. ANZ J Surg 2007; 77: 33-6.

22. Sorgato N, Pennelli G, Boschin IM, Ide EC, Pagetta C, Piotto A, et al. Can we avoid inadvertent parathyroidectomy during thyroid surgery?. In Vivo 2009; 23: 433-9.

23. Campos NS, Cardoso LP, Tanios RT, de Oliveiraa BC, Guimarães AV, Dedivitis $\mathrm{RA}$, et al. Risk factors for incidental parathyroidectomy during thyroidectomy. Braz J Otorhinolaryngol 2012; 78: 57-61.

24. Sakorafas GH, Stafyla V, Bramis C, Kotsifopoulos N, Kolettis T, Kassaras G. Incidental parathyroidectomy during thyroid surgery: an underappreciated complication of thyroidectomy. World J Surg 2005; 29: 1539-43.

25. Applewhite MK, White MG, Xiong M, Pasternak JD, Abdulrasool L, Ogawa L, et al. Incidence, risk factors, and clinical outcomes of incidental parathyroidectomy during thyroid surgery. Ann Surg Oncol 2016; 23: 4310-5.

26. Rajinikanth J, Paul MJ, Abraham DT, Ben Selvan CK, Nair A. Surgical audit of inadvertent parathyroidectomy during total thyroidectomy: incidence, risk factors, and outcome. Medscape J Med 2009; 11: 29.

27. Lee NJ, Blakey JD, Bhuta S, Calcaterra TC. Unintentional parathyroidectomy during thyroidectomy. Laryngoscope 1999; 109: 1238.

28. Matkovic V, Colachis SC, ilich JZ. Osteoporosis: Its prevention and treatment. Braddom R, Buschacher RM, Dumitru D, Johnson WE, Sinaki M, editors. Physcial Medicine and Rehabilition. Philadephia: Saunders; 1996.p.851-76.

29. Touliatos JS, Sebes JI, Hinton A, McCommon D, Karas JG, Palmieri GM Hypoparathyroidism counteracts risk factors for osteoporosis. Am J Med Sci 1995; 310: 56-60.

30. Fujiyama K, Kiriyama T, Ito M, Nakata K, Yamashita S, Yokoyama N, et al. Attenuation of postmenopausal high turnover bone loss in patients with hypoparathyroidism. J Clin Endocrinol Metab 1995; 80: 2135-8.

31. Mendonça ML, Pereira FA, Nogueira-Barbosa MH, Monsignore LM, Teixeira SR, Watanabe PC, et al. Increased vertebral morphometric fracture in patients with postsurgical hypoparathyroidism despite normal bone mineral density. BMC Endocr Disord 2013; 13: 1

32. Özden S, Erdoğan A, Simsek B, Saylam B, Yıldız B, Tez M. Clinical course of incidental parathyroidectomy: Single center experience. Aurius Nasus Larynx 2018; 45: 574-7.

33. Manatakis DK, Balalis D, Soulou VN, Korkolis DP, Plataniotis G, Gontikakis E. Incidental parathyroidectomy during total thyroidectomy: risk factors and consequences. Int J Endocrinol 2016; 2016: 7825305.

34. Song CM, Jung JH, Ji YB, Min HJ, Ahn YH, Tae K. Relationship between hypoparathyroidism and the number of parathyroid glands preserved during thyroidectomy. Word J Surg Oncol 2014; 12; 200.

35. Du W, Fang Q, Zhang X, Cui M, Zhao M, Lou W. Unintentional parathyroidectomy during total thyroidectomy surgery: A single surgeon's experience. Medicine (Baltimore) 2017; 96: 6411.

36. Zheng J, Song $\mathrm{H}$, Cai S, Wang $\mathrm{Y}$, Han X, Wu H, et al. Evaluation of clinical significance and risk factors of incidental parathyroidectomy due to thyroidectomy: A single-center retrospective clinical study. Medicine (Baltimore) 2017; 96: 8175.

37. Assessment of fracture risk and its application to screening for postmenopausal osteoporosis. Report of a WHO study group. 1994; 843: 1-129. 
38. Bone density measurement--a systematic review. A report from SBU, the Swedish council on technology assessment in health care. J Intern Med Suppl 1997; 739: 1-60

39. Johansson C, Mellström D. An earlier fracture as a risk factor for new fracture and its association with smoking and menopausal age in women. Maturitas 1996; 24: 97-106.
40. Concin H, Bischof HP, Taxer F, Ender K, Metka M, Heytmanek G. Menopausal bone density in healthy females of Voralberg. Lack of relation to anamnesis. Wien Med Wochenschr 1992; 142: 96-9.

41. Takamura Y, Miyauchi A, Yabuta T, Kihara M, Ito Y, Miya A. Attenuation of postmenopausal bone loss in patients with transient hypoparathyroidism after total thyroidectomy. World J Surg 2013; 37: 2860-5. 